\title{
VOORRAADBEHEERSING IN PRAKTIJK EN LITERATUUR
}

\author{
door Drs. L. J. Postma
}

\section{Algemene opmerkingen}

In de literatuur is aan systemen van voorraadbeheersing reeds lange tijd aandacht besteed. De over dit onderwerp verschenen boeken en tijdschriftartikelen variëren van zeer geavanceerd tot betrekkelijk eenvoudig.

Er moet helaas geconstateerd worden dat de in de literatuur vermelde systemen van voorraadbeheersing alsmede de daaruit ontworpen voorraadmodellen in het bedrijfsleven nog maar beperkt toegepast worden. De belangrijkste oorzaak hiervan is wel de vrij ingewikkelde mathematiek die bij de meeste voorraadmodellen gebruikt wordt. Er is hier duidelijk een kloof tussen praktijk en theorie aanwezig (practicality gap).

Onder invloed van de computer leveranciers, die op het terrein van voorraadbeheersing programmatuur aanbieden, beginnen thans betrekkelijk eenvoudige voorraadbeheersingssystemen bij het bedrijfsleven ingang te vinden. De aangeboden systemen zijn in belangrijke mate gebaseerd op de z.g. formule van Camp (ontwikkeld in de twintiger jaren). Deze formule, ook wel de formule van de optimale be- of instelserie (economic order quantity, E.O.Q. formule) genoemd, heeft tot doel de som van voorraad-en bestelkosten te minimaliseren. De formule werkt in zijn eenvoudigste vorm slechts met een beperkt aantal variabelen zoals be(in)stelkosten, voorraadkosten en verwachte vraag. Een van de centrale faktoren bij de formule van Camp (en trouwens ook bij de meeste andere voorraadbeheersingssystemen) is wel de schatting van de verwachte vraag. Voor deze vraagschatting zijn vele technieken ontworpen die in vele gevallen gebaseerd zijn op extrapolatie van historische reeksen. Van deze technieken staan op dit moment die van het voortschrijdende gemiddelde en ,exponential smoothing” wel het meeste in de belangstelling. Dit vanwege het feit dat zij betrekkelijk gemakkelijk te automatiseren zijn.

De formule van Camp is echter slechts onder bepailde voorwaarden toepasbaar. Een van de voorwaarden is b.v. een vrijwel continu verlopende afzet. De beperkingen van de formule van Camp worden niet altijd door de gebruikers ervan onderkend. Dit kan aanleiding geven tot niet gewenste voorraadsituaties.

Wat meer gecompliceerde voorraadmodellen waaronder z.g. multistage modellen beginnen thans ook uit het literatuurstadium te geraken. Daarbij gaat de idee veld winnen dat deze modellen niet in hun verfijnde literatuurvorm gebruikt behoeven te worden maar dat ook de hieruit afgeleide meer robuuste (grove) modellen reeds belangrijke verbeteringen in de voorraadsituatie kunnen geven. Het invoeren en op niveau houden is bij robuuste voorraadmodellen veelal aanzienlijk goedkoper dan bij meer verfijnde modellen. De kosten van de verfijnde modellen overtreffen vaak de besparingen die door een verbeterde voorraadsituatie worden verkregen.

Tevens gaat men de laatste tijd het voorraadmodel meer als onderdeel van een totaal bedrijfsmodel zien. Er zijn vele interdependenties tussen het voor- 
raadmodel en de andere onderdelen van het bedrijfsmodel. Voorraadbeheersing gaat evolueren naar material management, zijnde de beheersing van de goederenstroom in al zijn aspecten.

\section{Beknopte literatuuropgave inzake voorraadbeheersing}

De hieronder vermelde literatuur varieert van betrekkelijk eenvoudig tot tamelijk geavanceerd. $\mathrm{Zij}$ is op de gemiddelde lezer afgestemd.

1 A. Battersby. Voorraadbeheersing. Markaboeken. Utrecht 1965. Eenvoudig en gemakkelijk leesbaar boek. Bevat weinig wiskunde.

2 R. N. van Hees en W. Monhemius. Productiebesturing en voorraadbeheer, 2 delen. Eindhoven 1964 en Deventer 1970.

Deel $I$ is vrij elementair en geeft een algemene oriëntatie m.b.t. productiebesturing en voorraadbeheer. Er worden o.a. de formule van Camp, een aantal bestelsystemen en de practische toepassing van een eenvoudig voorraadbeheersingsysteem in behandeld.

Deel II is veel geavanceerder. Er worden varianten en uitbreidingen van de formule van Camp in besproken. Tevens wordt veel aandacht gegeven aan de bepaling van de verschillende variabelen bij een voorraadbeheersingssysteem. Ook komen meer geavanceerde voorraadbeheersingssystemen (zoals voorraadsystemen met meer voorraadpunten) aan de orde. Tenslotte worden nog enkele voorbeelden (w.o. een systeem van voorraadbeheersing van reserve-onderdelen) alsmede de aanpak van een voorraadbeheersings- en productiebesturingsprobleem besproken. Het is een uitstekend boek voor diegenen die reeds enigszins met het onderwerp voorraadbeheersing op de hoogte zijn.

3 G. W. Plossl and O. W. Wight. Production and Inventory Control. Englewood Cliffs 1967.

Dit boek is in hoofdzaak op de praktijk gericht. Veel aandacht wordt gegeven aan het gebruik van de z.g. Limit (Lot-size Inventory Management Interpolation Technique) techniek bij voorraadbeheersingsproblemen. De Limit-techniek is in feite een uitbreiding van de formule van Camp.

De behandeling van de problematiek is betrekkelijk eenvoudig. Het boek is bestemd voor een brede lezerskring. Het is als instructie- en leerboek bijzonder goed te gebruiken.

4 R. G. Brown. Decision Rules for Inventory Management. New York 1967.

Behandelt uitgebreid voorraadbeheersingsproblemen in een gefingeerde Amerikaanse onderneming. Aan de orde komen diverse voorraadbeheersingssystemen die echter in hoofdzaak gebaseerd zijn op de formule van Camp. Veel aandacht wordt gegeven aan vraagschattingstechieken, hetgeen trouwens een specialiteit van Brown is. De behandeling van de materie is vrij diepgaand.

5 G. Hadly and T. M. Whitin. Analysis of Inventory Systems. Englewood Cliffs 1963.

Dit boek bevat vele voorraadmodellen waaronder zeer geavanceerde. Het 
boek gaat vrij diep op de problematiek in en vereist van de lezer een behoorlijke mathematische achtergrond.

6 N.I.v.R.A. geschrift nr. 8. Voorraadbeheersing bij handelsbedrijven en de huidige praktijk ervan in Nederland. Amsterdam 1972.

Bevat de uitkomsten van een in $1968 \mathrm{t} / \mathrm{m} 1970$ gehouden onderzoek inzake voorraadbeheersing bij handelsbedrijven in Nederland. Uit dit onderzoek is gebleken dat een wetenschappelijke benadering van de voorraadproblematiek in Nederland bij handelsbedrijven (en vermoedelijk ook bij andere bedrijven) nog in de aanloopfase verkeert. De brochure bevat tevens een beknopte beschrijving van de algemene problematiek van voorraadbeheersing.

In veel O.R. tijdschriften verschijnen ook regelmatig artikelen over voorraadbeheersing. Deze artikelen behandelen vaak vrij complexe voorraadmodellen en zijn daardoor beperkt toegankelijk. Beter algemeen leesbaar is het Amerikaanse kwartaal-tijdschrift Production and Inventory Management, uitgegeven door APICS (American Production and Inventory Control Society). De artikelen die in dit tijdschrift opgenomen worden zijn duidelijk op een vrij brede lezerskring afgestemd. In Nederland is APICS vertegenwoordigd door de Vereniging van Voorraadbeheer en Productiebesturing, een vereniging die als een van haar doelstellingen heeft ,het overbruggen van de practicality gap". 